\title{
WORKER's REPRESENTATIVES IN COMPANIES AND THE Brazilian Constitution of 1988
}

\section{Representantes dos Trabalhadores em Empresas E A Constituição Brasileira DE 1988}

\section{RePresentantes de Los Trabajadores en Empresas y la Constitución Brasileña DE 1988}

\author{
Luiz Eduardo Gunther \\ Marco Antônio César Villatore** \\ Augustus Bonner Cochran III***
}

1 The ILO headquarters. 2 The Portuguese Model and the European Directive. 3 The debates which gave rise to art. $\mathrm{n}^{\circ}$. 11 of the Brazilian Constitution of 1988. 4 The proposals of regulation. 5 The Regulatory Wording of the Labor-law Reform. References.

\begin{abstract}
Objective: The objective of the research is to analyze whether the representation of workers in companies can validate collective bargaining in the same way as unions? What is the role of this commission in Brazil?

Professor at "Centro Universitário Curitiba" - UNICURITIBA. Labor Appellate Judge at the Labor Appellate Court, Region n. 9 - Pr; Post-Doctor from PUCPR; Member of the Brazilian Academy of Labor Law, of the "Instituto Histórico e Geográfico do Paraná" and of the "Centro de Letras do Paraná". Advisor of the Research Group which edits the "Revista Eletrônica do TRT9" (http://www.mflip.com.br/pub/escolajudicial/). Centro Universitário Curitiba - UNICURITIBA, Curitiba, PR, BR. E-mail: <luiz.gunther@uol.com.br>. http://orcid.org/0000-0002-0458-1362

** Professor at "Federal University of Santa Catarina" - UFSC. Lawyer. Post-Doctor from UNIROMA II - Tor Vergata; Member of the Brazilian Academy of Labor Law and of the "Centro de Letras do Paraná”. Leader of the NEATES. E-mail: <marcovillatore@gmail.com>. http://orcid.org/0000-00016365-6283

${ }^{* * *}$ Professor of Political Science at Agnes Scott College, Atlanta/Decatur, Georgia, USA. E-mail: <gcochran@agnesscott.edu>.https://orcid.org/0000-0003-3302-4992
\end{abstract}

R. Opin. Jur., Fortaleza, ano 18, n. 29, p.318-336, set./dez. 2020 
Methodology: the methodology used is deductive, as for the means, the research was bibliographic, using doctrine, legislation, ILO Convention. As for the purposes, the research was qualitative.

Results: The article analyzes the need for a constructive and democratic interpretation to enable the representation of workers effectively in our country.

Contributions: The workers' representation institute received ILO treatment through Convention No. 135 and Recommendation No. 143, both from 1971. The 1988 Constitution dealt with the subject in art.11, but the practical implementation of this body did not occur. Only with the 2017 labor reform was the issue regulated, allowing its implementation in Brazilian companies. Thus, the contribution is towards presenting a solution to the phenomenon of worker representation, via constructive and democratic interpretation.

Keywords: Workers. Representation. ILO. Constitution. Labor-law reform. Collective bargaining.

\section{RESUMO}

Objetivo: $\mathrm{O}$ objetivo da pesquisa é analisar se a representação dos trabalhadores nas empresas pode validar negociação coletiva da mesma forma que os sindicatos? Qual o papel dessa comissão no Brasil?

Metodologia: a metodologia utilizada é a dedutiva, quanto aos meios, a pesquisa foi bibliográfica, com uso de doutrina, legislação, Convenção da OIT. Quanto aos fins, a pesquisa foi qualitativa.

Resultados: $\mathrm{O}$ artigo analisa a necessidade de uma interpretação construtiva e democrática para viabilizar a representação dos trabalhadores efetivamente em nosso país.

Contribuições: $\mathrm{O}$ instituto da representação dos trabalhadores recebeu tratamento da OIT através da Convenção n.135 e da Recomendação n. 143, ambas de 1971. A Constituição de 1988 tratou do assunto no art.11, mas não ocorreu a implementação prática desse organismo. Somente com a reforma trabalhista de 2017 o tema foi regulamentado, permitindo sua implantação nas empresas brasileiras. Assim, a contribuição é no sentido de apresentar solução ao fenômeno da representação dos trabalhadores, via interpretação construtiva e democrática. 
Palavras-chave: Trabalhadores. Representação. OIT. Constituição. Reforma Trabalhista. Negociação coletiva.

\section{RESUMEN}

Objetivo: El objetivo de la investigación es analizar si la representación de los trabajadores en las empresas puede validar la negociación colectiva de la misma forma que los sindicatos. ¿Cuál es el papel de esta comisión en Brasil?

Metodología: la metodología utilizada es deductiva, en cuanto a los medios, la investigación fue bibliográfica, utilizando doctrina, legislación, convenio de la OIT. En cuanto a los propósitos, la investigación fue cualitativa.

Resultados: El artículo analiza la necesidad de una interpretación constructiva y democrática que posibilite la representación efectiva de los trabajadores en nuestro país.

Contribuciones: El instituto de representación de trabajadores recibió el tratamiento de la OIT a través del Convenio núm. 135 y la Recomendación núm. 143, ambos de 1971. La Constitución de 1988 abordó el tema en el artículo 11, pero no se produjo la implementación práctica de este órgano. Solo con la reforma laboral de 2017 se reguló el tema, permitiendo su implementación en empresas brasileñas. Así, la contribución es dar una solución al fenómeno de la representación de los trabajadores, a través de una interpretación constructiva y democrática.

Palabras clave: Trabajadores. Representación. OIT. Constitución. Reforma laboral. Negociación colectiva.

\section{THE ILO HEADQUARTERS}

The International Labour Organization - ILO, founded in 1919, by Part XII of the Treaty of Versailles, with the aim of promoting social justice, has been vital for the regulations, studies and investigation procedures on the main labor and social security problems in the world. In 2019, its 187 Member States celebrated the hundredth anniversary of the organization, which has in force 189 conventions, 205 recommendations and six protocols to the conventions (INTERNATIONAL LABOUR ORGANIZATION, 2019).

The Fifty-sixth Session of the General Conference of the International Labor Organization, held in Geneva, in 1971, adopted Convention $n^{\circ}$. 135, which deals with the representation of workers in companies. The international enforcement of the document occurred twelve months after the ratification was registered by two Members 
with the Director-General of the agency (art. 20 of the Constitution of the ILO) (ORGANIZAÇÃO INTERNACIONAL DO TRABALHO, 2019a).

Such an international document was enacted in Brazil under Legislative Decree $\mathrm{n}^{\circ} .86$, of December 14, 1989, by the Brazilian Congress. Next, this register was ratified with the ILO, on May 18, 1990. Finally, the enactment and publication took place under Decree $\mathrm{n}^{\circ}$. 131, by the President of Brazil, on May 22, 1991 (BRASIL, 1991). The date to be considered as the Brazilian enforcement is May 18, 1991, in accordance with the Preamble of the Decree itself.

The conventions of the ILO have a legal character of international treaties. Constitutional Amendment 45, of 2004, in Brazil, with the addition of $\S 3^{\circ}$. to art. $n^{\circ} .5$ of the Brazilian Constitution of 1988, required a qualified quorum, $3 / 5$ in votes of both houses of the Brazilian Congress for the treaties that deal with human rights, to be hierarchically considered constitutional amendments. The interpretation that $\S 2^{\circ}$. of art. $n^{\circ} .5$ of the Brazilian Constitution of 1988 had already made these treaties incorporate the block of constitutional law did not prevail. In 2008, when deciding Habeas Corpus and two extraordinary appeals, the Federal Supreme Court, in control of the conventionality of internal rules on the imprisonment of the depositary which unjustifiably refuses to return the thing deposited to the depositor, taking into account the Pact of San Jose, Costa Rica, held that the treaties on human rights which are integrated into the legal system are considered supralegal rules (BRASIL, 2008). Thus, all the conventions of the ILO that deal with human rights and which have already been internalized in Brazil can be so considered.

In addition to Convention $\mathrm{n}^{\circ}$. 135, Recommendation $\mathrm{n}^{\circ} .143$ must be mentioned as well; it was adopted by the General Conference of the ILO on June 23, 1971, and deals with the Protection and Facilities Afforded to Workers' Representatives in the Company (ORGANIZAÇÃO INTERNACIONAL DO TRABALHO, 2019b). The difference between the convention and the recommendation lies in the legal character of these kinds of instruments. The ratification of the former indicates that the Member State freely decided to adopt the obligations within the instrument. As for the recommendations, they cannot be ratified. They are mere guidelines to explain and assist the application of the convention. The Constitution of the ILO, however, grants "the right to request the Member State to submit a report to the Governing Board periodically, indicating to what extent the legislation and the national practices enforce the provisions of a recommendation." (SIBIRÉ, 1989, p.142-143).

Convention $\mathrm{n}^{\circ}$. 135 has already been ratified by 85 Member States, and according to its terms, workers' representatives in companies must enjoy effective protection against any measures which may be prejudicial to them. It should 
comprehend, in this regard, dismissal 'based on their status or activities as a workers' representative or on union membership or participation in union activities, in so far they act in conformity with existing laws or collective agreements or other jointly agreed arrangements.” (art. 1.) (INTERNATIONAL LABOUR ORGANIZATION, 2019, online). In companies, workers' representatives must also be allowed facilities so that they are able to carry out their functions in a prompt and efficient way (art. $2^{\circ}$.).

In this regard, the features of the system of professional relations that prevail in the country must be taken into account, as well as the needs, the significance and the possibilities of the company concerned. Recommendation $n^{\circ} .143$ defines the term "workers' representatives" (trade union representatives or elected) and points out that national laws and regulations, collective agreements, arbitration awards or court decisions may determine the types of workers' representatives that are entitled to the protection and to the facilities provided for in this recommendation.

When a company has trade union representatives and elected representatives, measures must be taken, if necessary, to ensure that the presence of the latter does not weaken the position of the trade unions concerned or of their representatives, and to encourage cooperation between the elected representatives and the trade unions concerned and their representatives. It is also considered possible to give effect to the convention by means of national legislation, collective rules or any other form of agreement in accordance with national practice (VALTICOS, 1977, p. 252).

Both Convention $n^{\circ} .135$ and Recommendation $n^{\circ} .143$ state that Member States are free to choose the most effective form of dialogue between the management of companies and the workers' representatives. They also provide for two traditional modes of representation: trade union representatives (designated or elected by trade unions or by their members) or representatives freely elected by the company's workers.

Recommendation $n^{\circ} .143$ especially refers to the protection and to the facilities to be afforded to workers' representatives in the company, including the following (art. $\left.n^{\circ} .6,2\right)$ :

a) detailed and precise definition of the reasons justifying termination of employment of workers' representatives;

b) a requirement of consultation with, an advisory opinion from, or agreement of an independent body, public or private, or a joint body, before the dismissal of a workers' representative becomes final;

c) a special appeals procedure open to workers' representatives who consider that their employment has been unjustifiably terminated, or that they have been subjected to an unfavorable change in their conditions of employment or to unfair treatment;

d) in respect of the unjustified termination of employment of workers' representatives, provision for an effective remedy which, unless this is contrary 
to basic principles of the law of the country concerned, should include the reinstatement of such representatives in their job, with payment of unpaid wages and with maintenance of their acquired rights;

e) provision for imposing on the employer, in the case of any alleged discriminatory dismissal or unfavorable change in the conditions of employment of a workers' representative, the burden of proving that such action was justified;

f) recognition of a priority to be given to workers' representatives with regard to their retention in employment in case of reduction of the workforce (ORGANIZAÇÃO INTERNACIONAL DO TRABALHO, 2019b, online). ${ }^{1}$

In the early 1950s, the Governing Board of the ILO set up the Committee on Freedom of Association, with the aim of examining the claims of violation or infringement of the instruments on the freedom of association as a whole. The aim of this Committee is to determine whether a concrete situation, from the point of view of legislation or in practice, conforms to the principles of freedom of association and of collective bargaining defined by conventions on such matters (ORGANIZAÇÃO INTERNACIONAL DO TRABALHO, 1997). Even though most of the issues presented are connected to the principles of freedom of association sanctioned in Conventions $\mathrm{n}^{\circ} .87$ and $\mathrm{n}^{\circ} .98$, the rules of Convention $\mathrm{n}^{\circ} .135$ are, at times, invoked by a claimant organization when there is a feeling that its 'delegates or workers' representatives elected in a company suffer injury on account of their mandate or of the activities they have been in charge for." (SIBIRÉ, 1989, p. 144). Among the numerous concrete cases submitted to the Committee of Freedom of Association, precedents $n^{\circ}$. 951 to $n^{\circ}$. 954, which summarize the trials of this organization, show cases related to workers' and trade unions' representatives, time for tasks and access to work places (SÜSSEKIND, 2000, p. 350-351).

The representation of workers in companies, therefore, is an essential device for the recognition of democracy in the relations inside enterprises, highlighting, in addition, the roles of the ILO in the regulation, guidance, and verification of such issues.

\section{THE PORTUGUESE MODEL AND THE EUROPEAN DIRECTIVE}

In the first half of the twentieth century, there were recorded instances of the formation of factory committees or commissions in France, Germany, Russia and England, with intense factual and doctrinal disputes, but also some useful experiences of

\footnotetext{
${ }^{1} \mathrm{R} 143$ - Of the protection and facilities afforded to workers' representatives in the undertaking.
} 
such participations. It was only from 1950 onwards that there can be seen a movement in favor of the cooperation between employees and employers in the core of private businesses. Such organizations start to receive specific names: company committees or boards, management boards, mixed committees of production, factory committees or boards, workers or employees' commissions, personnel delegates, among others. According to scholars on the subject, such experiences derive from a movement of trade unionism against capitalism, with a great economic interest, since such "apparent 'cooperation' of workers in corporate decisions has a psychological and social effect on the individual" (TAVEIRA, 2017, p. 269) ${ }^{2}$. It is noticed, thus, that "the more workers believe they take part in business decisions, the more productive and the more involved they are with the interests of the business organization." (TAVEIRA, 2017, p. 269).

The Portuguese constitutionalism has been very important in guiding legislative and doctrinal definitions in Brazil.

The Constitution of the Portuguese Republic refers to the representation of workers as "workers' committees". Art. $\mathrm{n}^{\circ} .54$, head of the article, fully registers these guarantees:

1. Workers have the right to form workers' committees to defend their interests and democratically intervene in the life of their enterprise.

2. Decisions to form workers' committees must be taken by the workers in question, who must approve the committees' by-laws, and must elect their members by direct, secret ballot.

3. Coordinating committees may be created with a view to improving intervention in economic restructuring and in such a way as to guarantee workers' interests.

4. Committee members enjoy the legal protection accorded to trade union delegates (PORTUGAL, 2005, online).

In six Subitems, the Constitution guarantees, in Item 5 of article $n^{\circ} .54$, the rights of workers' committees:

a) to receive all the information needed to do their work;

b) to monitor the management of their enterprises;

c) to participate in corporate restructuring processes, especially in relation to training actions or when working conditions are altered;

d) to take part in drawing up labor legislation and economic and social plans that address their sector;

e) to manage or participate in the management of their enterprise's social activities;

\footnotetext{
${ }^{2}$ Sobre o assunto: Gottschalk (1958, p. 8).
} 
f) to promote the election of workers' representatives to the governing bodies of enterprises that belong to the state or other public entities, as laid down by law (PORTUGAL, 2005, online).

The Portuguese law regulated this theme by means of the Law on Workers' Committees (Law $n^{\circ} .46$ of September 12, 1979), with 41 articles, and afterwards, with the Labor Code, in article $n^{\circ} .417$ :

1 - The number of employees' commission members may not exceed the following:

a) in an undertaking with fewer than 50 employees, two;

b) in a company with 50 or more employees and less than 200, three;

c) in a company with 201 to 500 employees, three to five;

d) in a company with 501 to 1,000 employees, five to seven;

e) in a company with more than 1,000 employees, seven to eleven.

2 - The number of members of subcommittees of employees cannot exceed the following:

a) in an establishment with 50 to 200 employees, three;

b) in an establishment with more than 200 employees, five.

3 - In an establishment with less than 50 employees, the function of the subcommittee shall be of only one member.

4 - The number of members of the coordinating committee may not exceed the number of committees of employees coordinated by it, nor a maximum of 11 members (PORTUGAL, 2009, online).

The European Union also regulated the principle of employees' representatives in undertakings by Directive 2009/38/EC (UNIÃO EUROPEIA, 2009), which guarantees the rights to information and consultation with regard to transnational issues of workers employed in community-scale companies (with at least one thousand workers) or in community-scale groups of companies, whose aim must be achieved through the establishment of a European Works Council or other procedures.

The main terms of the Directive are as follows:

* Information: the transmission of data by the employer to the employees' representatives in order to enable them to acquaint themselves with the subject matter and examine it for an assessment of the possible impact.

* Consultation: the establishment of dialogue between central management and representatives in order to enable them to express an opinion.

* Community-scale enterprise: any company which employs, at least, 1,000 workers in more than one country of the European Union and 150 workers in, at least, two of these countries.

* Community-scale group of enterprises: a group of companies that employs, at least, 1000 workers, has two companies in different countries of the European Union and employs 150 workers in, at least, two of these countries (UNIÃO EUROPEIA, 2016, online). 
This way, through the European Works Councils, employees are informed and consulted at a transnational level by the management of the company on the progress of their activities and on the significant decisions liable to affect them.

\section{THE DEBATES WHICH GAVE RISE TO ART. $\mathrm{N}^{\circ}$. 11 OF THE BRAZILIAN CONSTITUTION OF 1988}

The Constitution of 1988, for the first time in Brazilian history, provides for employees' representatives in companies. As it should be remembered, Labor Law has a wider scope than Labor Union Law. The former comprises other forms of workers' interlocutors with the companies, which are not only those connected to the union environment. This does not mean that union members are not important. They can exist in complex, democratic and highly technological societies, with other legitimate means of workers' representation, ensuring, obviously, exclusive freedom of collective bargaining to trade unions.

Art. n'. 11 of the Brazilian Federal Constitution of 1988 prescribes: "it is ensured, in companies with more than 200 employees, the election of a representative of the employees for the exclusive purpose of furthering direct negotiations with the employers." (BRASIL, 1988, online).

According to Estêvão Mallet and Marcos Fava, there is not such an identical provision in the previous Constitutions, "even though article $n^{\circ} .165$, VI, of the Federal Constitution of 1967, in accordance with Constitutional Amendment 1/1969, established the aim of the worker's integration in the life and development of the company" (MALLET; FAVA, 2013, p. 646-647), which, it is said, could be accomplished through the establishment of a personnel representative.

The insertion of this provision in the Constitution took place by means of Project B, on July 5, 1988, with the decision of the full court at the beginning of the second round. And with the same wording as it was later enacted, remained in Project C, of September 5, 1988, and in Project D, of September 21, 1988. The only change, between projects $C$ and $D$, is that in Project $C$ the article was given number 10, being given number eleven again in Project D, until its final enactment (LIMA et al., 2013, p. 95).

It can be seen that, at that time, the theme did not arouse great interest in the process of framing the Constitution. There were no suggestions, public hearings, thematic subcommissions or commissions regarding the subject. During the commission of systematization, in step $\mathrm{M}$, popular Amendment $\mathrm{n}^{\circ} .20 .720$ was adopted, but it concerned workers' participation in the taxable income of the company at the end of 
every financial year. In step $\mathrm{O}$, Amendment $\mathrm{n}^{\circ} .31 .551$ was rejected on the grounds that, the right to profit sharing having been recognized in the Constitution, the Congress would be in charge of its detailed ordinary regulation. In step S, Amendment nº 00.471 suggested the addition of a provision on the theme in the chapter of social rights. The reason given was that it would emphasize the significance of a direct agreement between employers and employees, aiming at greater integration and harmony in the workplace. The election of a workers' representative in companies with more than two hundred employees would guarantee a useful and necessary communication channel between the company and its employees.

The result of such an implementation would be an improvement of labor relations throughout the company, working out potential disagreements by means of direct bargaining.

It should be noted that all industrialized countries permit the existence, in the company, of not only one workers' representative, but also of workers' commissions, company's committees, boards, or whatever names they are given, aiming at creating a regime of co-responsibility within the company and conditions for the increase of workers' production, as, for instance, in West Germany, where codetermination was instituted (BRASIL, 2019).

The amendment that was passed in the Commission of Systematization questioned what the Brazilian experience would teach in this field of employment relationship. The answer was that the first companies which created workers' representatives were the multinationals. Since October 1980, Volkswagem do Brasil S. A. (São Bernardo) had established the election of representatives of hourly and monthly paid workers by department in the company. The system was expanded to other units of the company located in the towns of Taubaté, Santo Andre, and São Paulo. In addition, in Ford Brasil S. A., Saab Scania, Mercedes Benz, etc., workers' representatives were elected to reach agreements directly with the company (BRASIL, 2019).

The opinion favoring adoption understood that the proposal filled in the gap in the provision. Nonetheless, in step U, three proposals, which intended to suppress art. $\mathrm{n}^{\circ} .11$ of the Constitution Project (B) and the constant modifier "a" from the expression "a representative", were rejected. The rejection of the amendment to suppress the provision was grounded on the reason that the wording should remain in order to guarantee employees a better agreement with their employers. With that, access to the company's management would be constitutionally ensured. Statements of reasons to suppress the provision justified their position because of the weakening of the trade unions, since it allowed the "creation of powers parallel to those agencies". Another argument was that the matter should be dealt with in ordinary legislation, or, more 
appropriately, in the conventions or collective bargaining themselves. Both principles were rejected.

Another rejected amendment was one which suggested the suppression, in art. $\mathrm{n}^{\circ}$. 11, of the constant modifier "a" from the expression "a representative", justifying that the Constitution should not determine the number of workers' representatives in companies. The opinion for the rejection of such an amendment argued that, in addition to ensuring workers' representation with the company management, its continuance would avoid the mischaracterization of the idea, if there were too many elected for that purpose (BRASIL, 2019).

It took almost thirty years for the Brazilian legislature to overcome inertia for the full regulation of the provision.

\section{THE PROPOSALS OF REGULATION}

The first steps in the interpretation of the new Constitution pointed in the direction that the provision was self-enforcing. However, it was stated that it needed to be regulated to allow better applicability.

According to Arion Sayão Romita, "the Constitution does not oblige, only makes available, the election of the workers' representative. The provision is one of those with full efficacy, which does not depend on an ordinary law to enter into force." (ROMITA, 1991, p. 205). Other authors also spoke up along the same line, such as Lobo and Leite (1989, p. 309): "The precept is self-explanatory. It does not depend on further ordinary legislation." The same way, Estêvão Mallet and Marcos Fava considered the text selfenforcing, not assigning other conditions to the construction of the newly created provision. They pointed out that, for companies with less than two hundred employees, there was no imposition of an employees' representative. And, for those with more than two hundred employees, the election of one worker may not be enough only for the accomplishment of the mission sought by the rule.

Before the labor-law reform, which took place in 2017, documents were produced by the Brazilian Labor Forum, whose outcomes were summarized in the Report of the Commission of Systematization delivered to the President of Brazil in April 2004, based on which four proposed bills were prepared; two of them were introduced, the "Projeto Vicentinho-Maurício Rands de Representação dos Trabalhadores no Local de Trabalho" and the "Projeto de Ações Coletivas na Justiça do Trabalho", with a total of 234 articles (NASCIMENTO, 2011, p. 651). According to this proposal, the purposes of workers' representatives in companies were as follows: 
I - to represent workers in company management;

II - to improve the relationship between the company and its workers under the principles of good faith and mutual respect;

III - to promote dialogue and understanding in the workplace in order to prevent conflicts;

IV - to seek solutions for the conflicts derived from working relations, in a quick and effective way, aiming at the effective application of legal and contractual rules;

$\mathrm{V}$ - to mediate and settle individual employment conflicts;

VI - to ensure just and unbiased treatment to workers, preventing any form of discrimination due to gender, age, race, color, religion, political opinion, union participation, nationality or social background;

VII - to put forward specific claims of workers in their scope of representation;

VIII - to monitor the compliance with labor laws, social security laws and collective bargaining agreements (BRASIL, 2005, online).

It must be also added that, according to this proposed legislation, the commission should be formed by union initiative or a written request of $20 \%$ of the employees working longer than six months in the company. It provided for the following proportionality: from 30 to 80 employees, one representative; from 81 to 150 , two representatives; from 151 to 300, three; from 301 to 500, four; from 501 to 800, five; from 801 to one thousand, six representatives. In companies with more than a thousand employees, two representatives would be added for every thousand or fraction above five hundred employees. In companies with less than 30 employees, the commission should be created through a collective agreement. The election to choose the employees' representatives in this commission would be assigned to trade unions with recognized legal union status on the basis of the representation. The members of the employees' representation commissions would be protected against all acts of discrimination resulting from their participation, and the company should provide appropriate premises for the representatives to be able to perform their duties (BRASIL, 2005, online).

All these propositions, which were in the union reform legislation proposed by the Brazilian Labor Forum, are suspended at the moment because the union movement split up, indicating difficulties with approval, especially now, in the face of the labor law reform under implementation.

\section{THE REGULATORY WORDING OF THE LABOR-LAW REFORM}

Chronologically, we had the period between 1988 and 2017, almost 30 years, for the infra-constitutional legislature to pass the precept that established the employees' representation in undertakings come true.

329 • R. Opin. Jur., Fortaleza, ano 18, n. 29, p.318-336, set./dez. 2020 
When examining the provision on the theme in the Constitution, Arnaldo Süssekind presented three important interpretations regarding art. $\mathrm{n}^{\circ}$. 11: a) the duties of employees' representatives must be limited to the field of individual employment relations, configuring a two-way street between the company management and the employees; b) the personnel's representative, when fostering an agreement with the employers, as required by the Constitution, should respect the "union reserve", which mainly concerns the scope of collective issues, susceptible to collective bargaining; c) art. $\mathrm{n}^{\circ}$. 11 did not envision a union consultant, but rather "an employees' representative, to be elected by all workers and not only by those unionized." (SÜSSEKIND, 2013, p. 386).

Statutory law $n^{\circ}$. 13.467/2017, which established the labor-law reform under articles 510-A to 510-D, regulated the commission of employees' representatives in Brazil, terminating omission of the infra-constitutional legislature since 1988. After the effective date of the law, Provisional Presidential Decree $n^{\circ} .808$ was presented, whose new inclusion in the Consolidation of Labor Laws (CLL), art. 510-E, provided that such a commission did not replace the role of the trade union

to protect the rights and collective or individual interests of the category, including judicial or administrative issues, an event in which the participation of trade unions will be compulsory in collective bargaining, under the terms of Items III and VI of the head provision of art. $\mathrm{n}^{\circ} .8$ of the Constitution (BRASIL, 2017a, online).

This PPD was in force from November 14, 2017 to April 22, 2018, when it expired, because the Brazilian Congress did not pass it. The provision of the PPP encountered specialized doctrine, which did not recognize the full legitimacy of the employees' representation, avoiding a collision with what was provided in the Constitution. Regarding the subject, Melek (2017, p. 157) states:

"employees" representatives cannot ratify collective-bargaining agreements or collective labor agreements, at most being able to participate as observers, since such a duty is a responsibility of trade unions and that "employees" commissions cannot attempt to play the role of trade unions or even confound them.

In order to fill in the normative gap left by the above-mentioned expiration of PPD $n^{\circ}$. 808/2017, the Ministry of Labor published Regulation $n^{\circ}$. 349, on May 23, 2018, repeating, in art. $\mathrm{N}^{\circ} .8$, the wording of art. 510-E of the CLL almost literally. Note: 
The commission of employees' representatives, concerning Title IV-A of the Consolidation of Labor Law shall not replace the role of trade unions to protect the rights and collective or individual interests of the category, including judicial or administrative issues, such an event in which the participation of trade unions in collective bargaining will be compulsory, under the terms of Items III and VI of the head provision of art. n. 8 of the Federal Constitution (BRASIL, 2018, online).

In Brazil, so far, at least all the experiences in this sense have been either frustrating or tentative, in Homero Batista Mateus da Silva's point of view. However, he highlights the emergence of successful factory commissions "at the expense of the efforts of the employees themselves locally organized and in a ridiculously small number if compared to the dimension of the Brazilian industrial park." (SILVA, 2017, p. 123). This author, expanding the concept of non-unionized representation, presents as the only legitimate example, in the Brazilian legislation, "the one of the CIPA (International Commission of Accident Prevention), which is intended to be an agency aimed at health and occupational safety without direct interference from the union." (SILVA, 2017, p. 123). The mentioned scholar also has some doubts about PPD nº.808, which established art. 510-E, in the CLL, considering the presence of the union in collective bargaining indispensable, making it clear that factory commissions are not suitable to replace trade unions, whether in court or not. He points out the need to evaluate extreme cases where "the factory commission can take action in calling a strike in which the trade union is silent, and also, the action in collective bargaining in the face of inertia by unions, federations and confederations" - these events are legally provided in Law $n^{\circ} .7 .783 / 1989$, arts. $4^{\circ}$., $\S 2^{\circ}$., and $5^{\circ}$., and in the CLL, art. 617 , $\S 1^{\circ}$., in fine (SILVA, 2017, p. 125).

The duties of this commission of employees' representatives are provided in the seven Items of current art. 510-B, with a wording granted by Law $\mathrm{n}^{\circ} .13 .467 / 2017$, as follows: I - to represent the employees in company management; II - to improve the relationship between the company and its workers under the principles of good faith and mutual respect; III - to promote dialogue and understanding in the workplace in order to prevent conflicts, IV - to seek solutions for the conflicts derived from working relations, in a quick and effective way, aiming at the effective application of legal and contractual rules; $\mathrm{V}$ - to ensure just and unbiased treatment to workers, preventing any form of discrimination due to gender, age, race, color, religion, political opinion, union participation, nationality or social background; VI to put forward specific claims of workers in their scope of representation; VII - to monitor the compliance with labor laws, social security laws and collective bargaining agreements (BRASIL, 2017b). 
Franco Filho (2018, p. 20) explains that, as the trade unions in Brazil do not participate in such commissions, "it is advisable to insert an amendment to the individual employment contract to entitle representatives to absent themselves to take part in the commission. This right may be extended as resulting from Subitem 1 of article $\mathrm{n}^{\circ}$. 10 of Recommendation $\mathrm{n}^{\circ}$. 143, in which it is added that "workers' representatives in the company should be afforded the necessary time off from work, without loss of pay or social and fringe benefits, for carrying out their representation functions in the company" (ORGANIZAÇÃO INTERNACIONAL DO TRABALHO, 2019b, online). ${ }^{3}$

Generally speaking, doctrine presents an opinion in favor of the establishment of commissions, but also registers some doubts regarding their effectiveness. Francisco Meton Rodrigues de Lima and Francisco Péricles Rodrigues Marques de Lima emphasize that the functionality of such commissions is cooperation, mediation of internal conflicts, prevention and communication. The authors highlight that "in a large organization communication is poor, making the employer's command reach the bases in a distorted way, and there are several cases of employees who are mistreated, badlypaid, discriminated against without any knowledge by the company management." (LIMA; LIMA, 2017, p. 87). Because of that, they understand that an employees' commission "may be an efficient instrument to prevent the company from lawsuits against agents' inappropriate acts." (LIMA; LIMA, 2017, p. 87).

Likewise, other labor law writers are in favor of the existence of such commissions, which should have the major role of reaching an agreement directly with the employers. In order to be able to achieve this goal, the commission "shall act on behalf of adjustments, bringing the workers' claims, and acting in favor of a consensus, so that agreements are made with the aim of the good functioning of the company." (SOUZA JÚNIOR et al., 2018, p. 308-309). For such a direct agreement to occur, however, "the commission should have access to the company management without any intermediation, the commission even being entitled, in our opinion, to this direct channel to the employer." (SOUZA JÚNIOR et al., 2018, p. 309).

Despite all these statements in favor of the regulation of this principle, there still remain doubts regarding it. The first one: "can the company commissions be integrated in a union policy of improved dialogue and representation with workers in the representation of workers' interests?.” (NICOLADELI; PASSOS, 2018, p. 204). The second: "will the weak legal protection of the commission members against arbitrary discharge subject the employees' commission to the company's interests, or will it

\footnotetext{
${ }^{3} \mathrm{R} 143$ - Of the protection and facilities afforded to workers' representatives in the undertaking.
} R. Opin. Jur., Fortaleza, ano 18, n. 29, p.318-336, set./dez. 2020 
convert it into a union CIPA (International Commission of Accident Prevention)?" (NICOLADELI; PASSOS, 2018, p. 205).

The experience of the implementation of employees' representatives in companies may be successful, provided that it emerges and develops in a democratic environment, where the role, the functions and the limits of the elected to carry out these activities are clearly defined.

\section{REFERENCES}

BRASIL. Câmara dos Deputados. Centro de Documentação e Informação. Quadro histórico dos dispositivos constitucionais - art. 11. Available at: https://bd.camara.leg.br/bd/handle/bdcamara/32619. Access on: 10 May 2019.

BRASIL. Constituição da República Federativa do Brasil de 1988. Brasília, DF: Presidência da República, 1988. Available at: http://www.planalto.gov.br/ccivil_03/constituicao/constituicao.htm. Access on: 9 May 2019.

BRASIL. Decreto $\mathbf{n}^{\circ}$ 131, de 22 de maio de 1991. Promulga a Convenção $n^{\circ} 135$, da Organização Internacional do Trabalho - OIT, sobre a Proteção de Representantes de Trabalhadores. Brasília, DF: Presidência da República, 1991. Available at: http://www.planalto.gov.br/ccivil_03/decreto/1990-1994/D0131.htm. Access on: 9 May 2020.

BRASIL. Supremo Tribunal Federal. STF restringe a prisão civil por dívida a inadimplente de pensão alimentícia. 2008. Available at: http://www.stf.jus.br/portal/cms/vernoticiadetalhe.asp?idconteudo=100258. Access on: 10 May 2019.

BRASIL. Medida Provisória $\mathrm{n}^{\mathrm{o}}$ 808, de 14 de novembro de 2017. Altera a Consolidação das Leis do Trabalho - CLT, aprovada pelo Decreto-Lei no 5.452, de 1o de maio de 1943. Brasília, DF: Presidência da República, 2017a. Available at: http://www.planalto.gov.br/ccivil_03/_Ato2015-2018/2017/Mpv/mpv808.htm. Access on: 9 May 2019.

BRASIL. Lei no 13.467, de 2017. Altera a Consolidação das Leis do Trabalho (CLT), aprovada pelo Decreto-Lei no 5.452, de 1o de maio de 1943, e as Leis nos 6.019, de 3 de janeiro de 1974, 8.036, de 11 de maio de 1990, e 8.212, de 24 de julho de 1991, a fim de adequar a legislação às novas relações de trabalho. Brasília, DF: Presidência da República, 2017b. Available at: http://www.planalto.gov.br/ccivil_03/_ato20152018/2017/lei/113467.htm. Access on: 9 May 2019. 
BRASIL. Portaria no 349, de 23 de maio de 2018. Estabelece regras voltadas à execução da Lei no 13.467, de 13 de julho de 2017, no âmbito das competências normativas do Ministério do Trabalho. Available at: http://www.in.gov.br/materia//asset_publisher/Kujrw0TZC2Mb/content/id/15752792/do1-2018-05-24-portaria-n349-de-23-de-maio-de-2018-15752788. Access on: 10 May 2019.

BRASIL. Ministério do Trabalho e Emprego. Fórum Nacional do Trabalho. Anteprojeto de Lei da Reforma Sindical. Brasília, 2005. Available at: http://www.sintunesp.org.br/sindtrab/Ref_SindAnteprojeto14-02-05.pdf. Access on: 14 May 2019.

FRANCO FILHO, Georgenor de Sousa. Reforma trabalhista em pontos: de acordo com a Lei no 13.467/17 e a MP nº 808/17. São Paulo: LTr, 2018.

GOTTSCHALK, Elson Guimarães. A participação do empregado na gestão da empresa. Bahia: Livraria Progresso Editora, 1958.

INTERNATIONAL LABOUR ORGANIZATION. Normlex - Information System on International Labour Standards. As of Today. Available at: https://www.ilo.org/dyn/normlex/en/f?p=NORMLEXPUB:1:0::NO:::. Access on: 9 May 2019.

LIMA, Francisco Meton Rodrigues de; LIMA, Francisco Péricles Rodrigues Marques de. Reforma trabalhista: entenda ponto por ponto. São Paulo: LTr, 2017.

LIMA, João Alberto de Oliveira et al. A gênese do texto da Constituição de 1988. Brasília: Senado Federal, Coordenação de Edições Técnicas, 2013.

LOBO, Eugenio Haddock; LEITE, Julio Cesar do Prado. Comentários à Constituição Federal: $1^{\circ}$ vol. arts. $1^{\circ}$ a 11 . Rio de Janeiro: Edições Trabalhistas, 1989.

MALLET, Estêvão; FAVA, Marcos. Comentários ao art. 11. In: CANOTILHO, J. J. Gomes; MENDES, Gilmar F.; SARLET, Ingo W. (coord.). Comentários à Constituição do Brasil. São Paulo: Saraiva/Almedina, 2013.

MELEK, Marlos Augusto. Trabalhista! O que mudou? Reforma trabalhista 2017. Curitiba: Estudo Imediato Editora, 2017.

NASCIMENTO, Amauri Mascaro. Compêndio de direito sindical. 6. ed. São Paulo: LTr, 2011.

NICOLADELI, Sandro Lunard; PASSOS, André Franco de Oliveira. Comissão de empresa e representantes no local de trabalho na "CLT reformada". In: DALLEGRAVE 
NETO, José Affonso; KAJOTA, Ernani (coord.). Reforma trabalhista ponto a ponto: estudos em homenagem ao professor Luiz Eduardo Gunther. São Paulo: LTr, 2018. p. 198- 205.

ORGANIZAC̣ÃO INTERNACIONAL DO TRABALHO. A liberdade sindical. 1997. Available at: https://www.ilo.org/wcmsp5/groups/public/-mamericas/mro-lima/--ilobrasilia/documents/publication/wcms_231054.pdf. Access on: 14 May 12019.

ORGANIZAÇÃO INTERNACIONAL DO TRABALHO. Constituição da Organização Internacional do Trabalho (OIT) e seu anexo (Declaração de Filadélfia). Available at: https://www.ilo.org/wcmsp5/groups/public/-mamericas/-ro-lima/--ilobrasilia/documents/genericdocument/wcms_336957.pdf. Access on: 9 May 2019a.

ORGANIZAÇÃO INTERNACIONAL DO TRABALHO. R 143 - Sobre Proteção e Facilidades a serem Dispensadas a Representantes de Trabalhadores na Empresa. Available at: https://www.ilo.org/brasilia/convencoes/WCMS_242718/langpt/index.htm. Access on: 9 May 2019b.

PORTUGAL. Código do Trabalho. Lei $\mathrm{n}^{\circ} 7 / 2009$. Available at: https://dre.pt/web/guest/legislacao-consolidada//lc/108165886/201710020100/73482234/diploma/indice. Access on: 10 May 2019.

PORTUGAL. Constituição da República Portuguesa. 2005. Available at: https://www.parlamento.pt/Legislacao/paginas/constituicaorepublicaportuguesa.aspx. Access on: 9 May 2019.

ROMITA, Arion Sayão. Os direitos sociais na Constituição de outros estudos. São Paulo: LTr, 1991.

SIDIBÉ, Th. Normas internacionais sobre representantes dos trabalhadores na empresa. In: TEIXEIRA FILHO, João de Lima (coord.). Relações coletivas de trabalho: estudos em homenagem ao Ministro Arnaldo Süssekind. São Paulo: LTr, 1989. p. 139-144.

SILVA, Homero Batista Mateus da. Comentários à reforma trabalhista. 2. ed. São Paulo: Editora Revista dos Tribunais, 2017.

SOUZA JÚNIOR, Antonio Umberto de et al. Reforma trabalhista: análise comparativa e crítica da Lei no 13.467/2017 e da Medida Provisória no 808/2017. 2. ed. São Paulo: Rideel, 2018.

SÜSSEKIND, Arnaldo. Direito internacional do trabalho. 3. ed. atual. com novos textos. São Paulo: LTr, 2000. 
SÜSSEKIND, Arnaldo. Representação de empregados na empresa. In: PINTO, José Augusto Rodrigues; MARTINEZ, Luciano; MANNRICH, Nelson (coord.). Dicionário brasileiro de direito do trabalho. São Paulo: LTr, 2013.

TAVEIRA, Roselene Aparecida. A comissão de representação de empregados na lei no 13.467/2017. In: FERREIRA, Olavo Augusto Vianna Alves; MENDES, Márcia Cristina Sampaio (coord.). Reforma trabalhista. Ribeirão Preto: Migalhas, 2017. p. 265-275.

UNIÃO EUROPEIA. Directiva 2009/38/CE do Parlamento Europeu e do conselho de 6 de Maio de 2009 relativa à instituição de um Conselho de Empresa Europeu ou de um procedimento de informação e consulta dos trabalhadores nas empresas ou grupos de empresas de dimensão comunitária. Available at: https://eurlex.europa.eu/legal-content/PT/TXT/?uri=celex:32009L0038. Access on: 10 May 2019.

UNIÃO EUROPEIA. Informação e consulta dos trabalhadores: Conselho de Empresa Europeu. 2016. Available at: https://eur-lex.europa.eu/legalcontent/PT/TXT/?uri=LEGISSUM\%3Aem0019. Access on: May 10, 2019.

VALTICOS, Nicolas. Derecho internacional del trabajo. Tradução Maria José Triviño. Madrid: Tecnos, 1977.

\section{NOTE}

The three authors constructed the scientific article sharing information, research, studies, reflections and the writing of the final text. The first author presented the bibliographic research along with preliminary preparation of the article in compliance with the journal's rules. The second author presented additions to the article, especially in the area of the International Labor Organization, taking responsibility for the necessary part in Spanish. The third author complemented the work in relation to the European Union and revised the entire text, suggesting appropriate revisions in terms of content, and drafted the English version.

How to cite this document:

GUNTHER, Luiz Eduardo; VILLATORE, Marco Antônio César; COCHRAN III, Augustus Bonner. Workers' representatives in undertakings and the Brazilian Constitution of 1988. Revista Opinião Jurídica, Fortaleza, v. 18, n, 29, p. 318-336, set./dez. 2020. 